\title{
THE RELATIONSHIP BETWEEN THE FORWARD AND REALISED SPOT EXCHANGE RATE IN SOUTH AFRICA
}

\author{
Chris van Heerden* \\ North West University \\ Chris.vanheerden@nwu.ac.za \\ André Heymans\# \\ North West University \\ Andre.Heymans@nwu.ac.za
}

December 2011

\begin{abstract}
It is well known that the forward exchange rate and the realised future spot exchange rate differ. This phenomenon is better known as the exchange rate puzzle. Two approaches were followed to ascertain whether this difference is due to the weak explanatory ability of current economic fundamentals or whether the use of an ineffective econometric approach to model exchange rate theories is to blame. The first approach makes use of stationary economic time series data to model the ZAR/USD realised future spot exchange rate, while the second uses non-stationary level economic data to model the ZAR/USD realised future spot exchange rate. While the first approach reported weak results, the second approach illustrated that economic fundamentals are able to explain the ZAR/USD realised future spot exchange rate. These results also confirm that the exchange rate puzzle is a pseudoproblem.
\end{abstract}

\section{Keywords}

Economic fundamentals; exchange rate puzzle; forward exchange rate; fractionally differenced data; nonstationary data; realised future spot exchange rate; stationary data.

\footnotetext{
*Dr Chris van Heerden is a senior lecturer in the School of Economics at the Potchefstroom Campus of North West University, South Africa.

\#Dr André Heymans is a senior lecturer in the School of Economics at the Potchefstroom Campus of North West University, South Africa.
} 


\section{INTRODUCTION}

The value of the South African Rand (ZAR) is still experiencing extensive swings under the freely floating exchange rate regime. The ZAR experienced significant shocks during 1970-1995 owing to political events in the local economy, intensified sanctions against South Africa, large gold price movements as well as capital outflows. The introduction of the Financial Rand System in September 1985 was an attempt to limit these capital outflows from South Africa. However, the abolishment of the Financial Rand System in 1995 relaxed the exchange control over non-South African residents and on capital outflows, thus escalating the volatility of the South African exchange rate. The ZAR, as an emerging economy currency, was also vulnerable to fluctuations caused by the Asian crisis (1997), the Russian crisis (1998), the Brazilian crisis (1999), the Argentinean crisis (2001/2002), and the preliminary shocks of the world financial crisis $(2007 / 2008)$. The ZAR underwent significant fluctuations during 2000, when the nominal effective exchange rate depreciated by $12.5 \%$, and again in 2001 , when it depreciated by $34.5 \%$. However, during 2002 the nominal effective exchange rate appreciated by $26 \%$ and again by $19 \%$ in the first quarter of 2003 (Van der Merwe, 2003). The recovery of the ZAR in 2002 and in the first four months of 2003 was the first in 30 years and can be ascribed to the macroeconomic policies followed at that time (Van der Merwe, 2003). The ZAR, however, continues to fluctuate, to a large extent between R5/USDI and R8/USDI.

These continuous fluctuations in the ZAR/USD exchange rate make it difficult to determine future exchange rate movements, thus hindering the day-to-day decision-making processes of investors, traders, and policy makers. As a result, market participants started using the forward exchange rate as an indicator to help estimate the expected future exchange rate. In order to determine what the forward exchange rate would be for a certain period, the daily quoted forward points are being used. This is however not very effective. The large difference between the forward exchange rate and the ZAR/USD spot exchange rate makes this approach ineffective for market participants. This was also emphasised by, among others, Diamandis, Georgoutsos and Kouretas (2008) and Albuquerque (2008), who stated that the forward exchange rate is a biased estimate of the realised future spot exchange rate.

FIGURE 1 provides a further illustration that the forward exchange rate follows the same trend as the current spot exchange rate, except for the small difference that consists mainly of the carry cost of the transaction. The reason is that the current method used by South African banks to quote the forward exchange rate is a mechanical approach. This is a fact that seems not to be widely known or recognised, especially by academics. The importance of this fact will be a focus point of this paper.

The primary question posed in this investigation is thus whether current (time $t$ ) economic fundamentals (from the capital and goods markets) are able to explain the realised future spot exchange rate (time $t+1$ ), in light of the current mechanistic determination of the forward exchange rate. The secondary, related, question is whether the exchange rate puzzle is not a pseudo-fallacy caused by the rigorous, unyielding practice of exclusively using stationary time series in the investigations into this 'puzzle'. This paper will also incorporate the interactions of the international financial markets into an exchange rate model as an additional economic fundamental to explain the realised future spot exchange rate. This alternative approach attempts to incorporate market expectations more effectively. This paper will start by providing a background (Section 2) on past literature studies, and this will be followed by a discussion of the methodology (Section 3) and the reporting of the results (Section 4). 


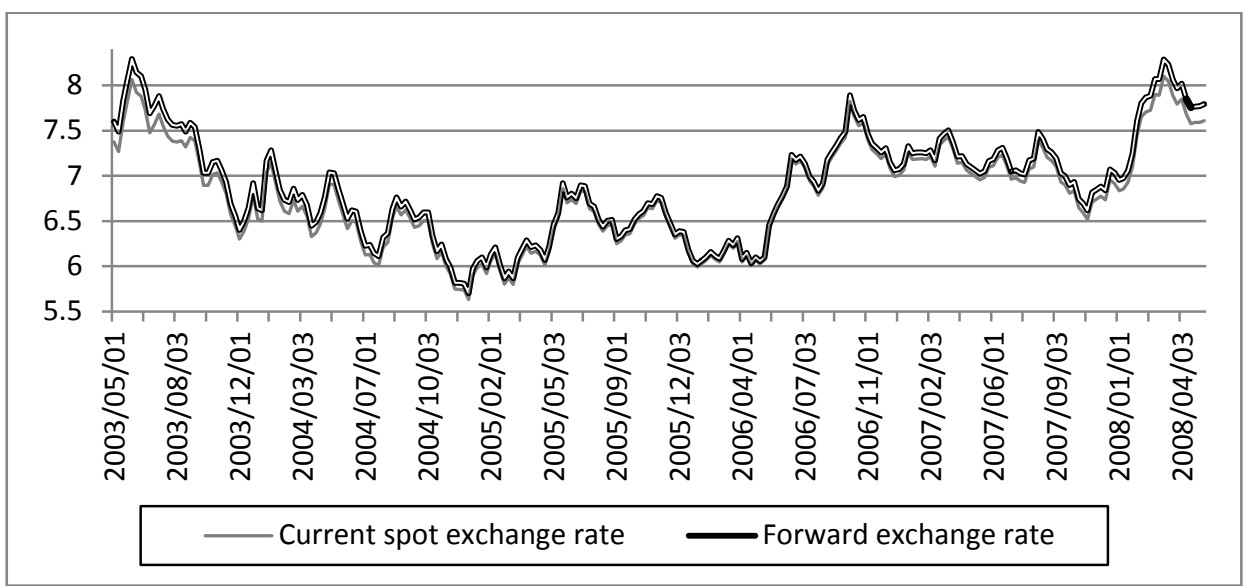

FIGURE 1: The current ZAR/USD spot and 3-month forward exchange rate

Source: McGregor BFA database

\section{BACKGROUND}

There is a substantial amount of literature on the difference between the forward exchange rate and the realised future spot exchange rate. However, very few of these studies, which are mainly theoretical in nature, took cognisance of the fact that in most countries the actual day-to-day determination of the forward exchange rate is more mechanistic and less based on economic fundamentals. Most academic studies focus on the economic fundamentals that can possibly explain the forward exchange rate on the date that the forward exchange rate contract matures, without even mentioning the mechanistic price formulation methodology used in the foreign exchange markets. Examples of these studies include the study by Ott and Veugelers (1986), which stated that the forward exchange rates, which estimate future spot exchange rates, are influenced by changing inflation rate differentials, interest rate differentials, and the monetary policy in the two different countries. According to Korajczyk's (1985) study, the foreign exchange rate premium can be explained by real interest rates. Huang (1990), however, found that the Purchasing Power Parity (PPP) approach may yield better results than interest rate differentials in determining the forward exchange rate premium. Thus, the inflation rate and the interest rate have been empirically identified as possible preliminary explanatory factors of exchange rate movements and the starting point for formulating an exchange rate model. Morley and Pentecost (1998) and Chiang (1991) add to this list of explanatory macroeconomic factors, finding that the exchange rate premium is also related to expected equity premiums. To this end, Jiang and Chiang (2000) found that exchange rate excess returns are correlated with the volatility in stock and currency markets. This implies that dual-listed stock returns may incorporate the volatility between two stock exchanges and the exchange rates used by them, thus making it possible to generate a more accurate realised future spot exchange rate. This would be possible since the prices of dual-listed stocks still differ on each exchange, in contrast to the single market hypothesis (Ip \& Brooks, 1996). The prices of dual-listed stocks being different on the different markets provides additional information regarding the future movement of the spot exchange rate, thus enhancing the ability to incorporate market expectations into an exchange rate model. 
However, despite all these additions to both the micro- and macroeconomic-based models developed for the purpose of estimating the realised spot exchange rate, their performance remained dismal (see for example Lyons (2001), Lyons (2002), and Sarno \& Taylor (2001) on micro-models and Obstfeld \& Rogoff (1995), Obstfeld \& Rogoff (2000), and Chiang \& Yang (2007) on macro-models). Mussa (1990:2) elaborates on this dilemma, stating that

The most consistently observed fact concerning the behaviour of floating exchange rates is that changes in exchange rates are largely random and unpredictable.

Central to this issue of the exchange rate puzzle (the weak ability of the forward exchange rate to explain the realised spot exchange rate) is the methodology used in the econometric modelling and data analysis of the puzzle. Current exchange rate modelling is erroneously based on the condition that all data must be stationary. Most research claims that the failure to comply with this condition will result in spurious regression results, statistically insignificant estimations, and nonsensical parameter signs. Since differencing a series (making it stationary) may not always prevent spurious results (Ventosa-Santaulària, 2009) these claims are not always valid. Phillips (1998) and Ventosa-Santaulària (2009) for example also argued that nonstationary level data can be used in exchange rate modelling, without the 'fear' of spurious results, provided that the correct econometric techniques are used. In following a stationary approach, time series data must be adjusted for the presence of a unit root, thus generating a weakly stationary series, a second-order stationary series, or a stochastic process (Gujarati, 2003). Also, when estimating an Ordinary Least Squares (OLS) model preventative measures should be taken for spurious regressions, which are visible in OLS models with high R-squares, low Durbin Watson statistics, and highly statistically significant coefficients (Gujarati, 2003). Such measures include the rule of thumb that states that there are no spurious results as long as the R-squared value is smaller than the Durbin Watson statistic (Granger \& Newbold, 1974). However, the study by Ventosa-Santaulària (2009) argued that this rule of thumb may be statistically insignificant and by differencing a series spurious estimates may not always be prevented. Additional warning signs of spurious regressions in OLS models that incorporated stationary and highly persistent variables also include inconsistent standard errors that are used in the $t$-ratios (Ventosa-Santaulària, 2009).

Furthermore, unit root processes have limitations when modelling economic theories, because a unit root model can be rejected

in favour of a trend "alternative" when in fact that alternative model is nothing other than an alternative representation of the unit process itself (Phillips, 1998:1317).

This also further implies that neither unit root models nor deterministic trends have the ability to model economic theory adequately (Ventosa-Santaulària, 2009). Least Squares models also have some limitations when investigating non-stationary time series data, which include the potential for interpreting results incorrectly, because results can become misleading if causality and correlation are confused. This contributed to the notion of differentiating non-stationary time series data when estimating regressions or when attempting to 'de-trend' time series data by fitting trend lines in the estimation of Least Squares models (Ventosa-Santaulària, 2009).

The empirical study will, therefore, consist of two main approaches. The first approach includes the use of stationary economic time series to model the realised future exchange rate, while the second approach will make use of non-stationary economic level data to model the future realised exchange rate. 


\section{METHODOLOGY}

Since the ZAR/USD spot exchange rate exhibits long-memory characteristics, it does not completely follow a random walk (van Heerden, 2010). This validates the use of economic fundamentals to enhance the explanation of the realised future spot exchange rate. In an attempt to combine the applicable models and variables identified from the literature into one comprehensive model, the methodology of Chiang and Yang (2007) was identified as an ideal starting point.

This model consists of a linear combination of the International Equity Parity, the PPP, the Uncovered Interest Rate Parity, and the expected hypothesis of the domestic term structure of interest rates. The Chiang and Yang (2007) methodology can be illustrated as follows:

$$
\begin{aligned}
& s_{t+3}-f_{t}=\alpha+\rho\left[\left(\Delta p_{t+k}^{e}-r_{t}\right)-\left(\Delta p_{t+k}^{* e}-r_{t}^{*}\right)\right]+\delta\left[\left(R_{t+k}^{e}-r_{t}\right)-\left(R_{t+k}^{* e}-r_{t}^{*}\right)\right]+ \\
& \gamma\left[\left(r_{t}^{L}-r_{t}\right)-\left(r_{t}^{* L}-r_{t}^{*}\right)\right]+\varepsilon_{t}
\end{aligned}
$$

where:

$\mathrm{t}$ is the number of months;

$\mathrm{k}$ is the number of months forecasted;

$\mathrm{s}_{\mathrm{t}+3}$ is the spot ZAR/USD exchange rate at time $\mathrm{t}+3$;

$\mathrm{f}_{\mathrm{t}}$ is the forward ZAR/USD exchange rate at time $\mathrm{t}$;

$\alpha$ is the constant parameter;

$\rho$ is the real risk-free interest rate differential coefficient;

$\delta$ is the risk-free stock return differential coefficient;

$\gamma$ is the risk-free long-run yield differential coefficient;

$\Delta \mathrm{p}_{\mathrm{t}+\mathrm{k}}^{\mathrm{e}}$ and $\Delta \mathrm{p}_{\mathrm{t}+\mathrm{k}}^{* \mathrm{e}}$ are the expected inflation rates of South Africa and the U.S.A., respectively;

$r_{t}$ and $r_{t}^{*}$ are the South African 91-day T-Bill rates and the 91-day T-Bill rates of the U.S.A., respectively;

$\mathrm{R}_{\mathrm{t}+\mathrm{k}}^{\mathrm{e}}$ and $\mathrm{R}_{\mathrm{t}+\mathrm{k}}^{* \mathrm{e}}$ are the expected returns generated from stock indices or from individual resource dual-listed stocks of South Africa and the U.S.A., respectively;

$r_{t}^{L}$ and $r_{t}^{* L}$ are the South African long-run 10-year government bond yield rates of South Africa and of the U.S.A., respectively; and

$\varepsilon_{t}$ is the random error.

The $\left[\left(R_{t+k}^{e}-r_{t}\right)-\left(R_{t+k}^{* e}-r_{t}^{*}\right)\right]$ bracket illustrates that expected stock returns are used to estimate the preliminary Chiang and Yang (2007) model. An alternative method was applied in generating expected inflation rate and expected stock return values. These expected values were generated by means of an exponential weighting procedure and Exponential Weighted Moving Average (EWMA) model. With this alternative method it is possible to incorporate both historical expectations and future expectations into present expectations.

In addition to the use of an expected stock return differential, the $\left[\left(R_{t+k}^{e}-r_{t}\right)-\left(R_{t+k}^{* e}-r_{t}^{*}\right)\right]$ 
bracket will also be substituted with alternative proxies. These alternatives include the price difference between the dual-listed stocks (in USD terms), the ICAPM series, and the speed of adjustment series of the AngloGold Ashanti Limited and Sappi Limited dual-listed stocks. The empirical results indicate that the use of a composed variable (the expected stock return differential) as suggested by the Chiang and Yang (2007) methodology, as well as the speed of adjustment series, failed to provide a statistically significant contribution to the exchange rate model. However, further investigation illustrated that the price difference of the AngloGold Ashanti Limited dual-listed stocks, in USD terms, provided a more significant contribution.

In order to gain more information regarding market expectations (the volatility spill-over effect), a speed of adjustment series was used as a proxy for the interaction between two international financial markets. The two markets under investigation are the Johannesburg Stock Exchange (JSE) and the New York Stock Exchange (NYSE).

Data was collected from a number of databases (see TABLE Al in the appendix), spanning from 1 May 1994 to 31 May 2008, thus covering a period of 14 years. This time frame starts just before the election of Nelson Mandela as South African president, which took place on 9 May 1994, and ends before the outbreak of the world financial crisis, which started approximately on 9 September 2008 when Lehman Brothers announced their bankruptcy. However, due to the lack of data for some of the dual-listed stocks, the time frame was adjusted to 1 May 2003 to 31 May 2008 for the applicable stocks. After the monthly inflation expectations were generated with the use of an exponential weighting procedure and an Exponential Weighted Moving Average (EWMA) model a linear interpolation process was used to convert the year-on-year monthly PPI data into a weekly format. All the daily time series data was also converted into a weekly format by using a five-day average for each week.

Two approaches were followed in modelling the realised future spot exchange rate. The first approach makes use of stationary data, while the second employs non-stationary level data. Different formats were examined in order to make the data stationary; these include the logformat, the first differencing format, and the fractional differencing format. The first differencing format entails the use of the change in the variables from period $t$ to period $t+1$. The first differencing and fractional differencing formats provided the best results and will be used for the stationary approach. The study by Granger and Newbold (1974) also supported the first differencing format approach, arguing that no information in the time series will be lost by using changes. The following sections will report the results found for following the stationary approach (Section 3.1) and the non-stationary approach (Section 3.2).

\subsection{The first approach (stationary data format)}

Before the Chiang and Yang (2007) methodology can be fully examined, the presence of the exchange rate puzzle in the ZAR/USD exchange rate must first be established. In order to determine the presence of an exchange rate puzzle the following adjusted equation was estimated (Chiang \& Yang, 2007):

$$
s_{t+k}-f_{t}=v_{0}+v_{1}\left(f_{t}-s_{t}\right)+\varepsilon_{t+k}
$$

where:

$\mathrm{s}_{\mathrm{t}+\mathrm{k}}$ is the spot ZAR/USD exchange rate at time $\mathrm{t}+\mathrm{k}$;

$\mathrm{k}$ represents the number of months ahead; 
$f_{t}$ is the forward ZAR/USD exchange rate at time $t$;

$\mathrm{v}_{0}$ is the constant parameter;

$\mathrm{v}_{1}$ is the exchange rate premium coefficient; and

$\varepsilon_{\mathrm{t}+\mathrm{k}}$ is the random error.

The first differencing format was applied to make all the variables stationary. The results reported in TABLE 1 were obtained by estimating an Ordinary Least Squares (OLS) model. The present premium $\left(\mathrm{f}_{\mathrm{t}}-\mathrm{s}_{\mathrm{t}}\right)$ could explain only $16 \%$ of the future premium $\left(\mathrm{s}_{\mathrm{t}+3}-\mathrm{f}_{\mathrm{t}}\right)$, thus indicating the presence of an exchange rate puzzle in the ZAR/USD exchange rate. Although the second differencing format (fractionally differenced data) rendered improved results (see TABLE 2), the present premium $\left(\mathrm{f}_{\mathrm{t}}-\mathrm{s}_{\mathrm{t}}\right)$ still only explains $26 \%$ of the future premium $\left(\mathrm{s}_{\mathrm{t}+3}-\mathrm{f}_{\mathrm{t}}\right)$. The Durbin Watson statistic and the Ramsey Reset test also indicate that the model is misspecified.

TABLE 1: The forward premium hypothesis (OLS) - first differenced approach

\begin{tabular}{lccccc}
\hline \multicolumn{2}{c}{ Dependent: Difference of $\left(s_{t+3}-f_{t}\right)$} & & Coefficient & $\begin{array}{c}\text { Std. } \\
\text { error }\end{array}$ & $t$-prob. \\
\hline Difference of $\left(\mathrm{f}_{\mathrm{t}}-\mathrm{s}_{\mathrm{t}}\right)$ & & & -17.545 & 2.641 & $0.000^{\star}$ \\
Constant parameter $\left(\mathrm{v}_{0}\right)$ & & & -0.003 & 0.011 & 0.796 \\
R-squared & 0.155 & Prob.(F-statistic) & 0.000 & & \\
Adjusted R-squared & 0.151 & AIC & -0.726 & Durbin Watson & 1.612 \\
\hline
\end{tabular}

Source: Compiled by authors

* Statistically significant at the $5 \%$ level

TABLE 2: The forward premium hypothesis - fractionally differenced approach (OLS)

\begin{tabular}{|c|c|c|c|c|c|c|}
\hline \multicolumn{4}{|c|}{ Dependent: Fractionally difference $\left(s_{t+3}-f_{t}\right) d$} & Coefficient & $\begin{array}{l}\text { Std. } \\
\text { error }\end{array}$ & $t$-prob. \\
\hline \multicolumn{4}{|c|}{ Fractionally differenced $\left(\mathrm{f}_{\mathrm{t}}-\mathrm{s}_{\mathrm{t}}\right)$} & -4.377 & 0.477 & $0.000 *$ \\
\hline \multicolumn{4}{|c|}{ Constant parameter $\left(\mathrm{v}_{0}\right)$} & 0.354 & 0.068 & $0.000 *$ \\
\hline R-squared & 0.259 & Prob.(F-statistic) & 0.000 & & & \\
\hline Adjusted R-squared & 0.256 & AIC & 0.190 & \multicolumn{2}{|c|}{ Durbin Watson } & 0.458 \\
\hline
\end{tabular}

Source: Compiled by authors

* Statistically significant at the $5 \%$ level.

As is clear from the results, additional explanatory variables are needed to improve the estimation of the future spot exchange rate. To this end the following changes were made to the model. An AR(1) variable was included to eliminate the presence of serial correlation. The Chow breakpoint and Cusum tests indicated that two dummies were also required. Intercept dummies were thus included to improve the accuracy of the estimation of the multi-variable model. Dummy 1 ranged from the second week in July 2006 to the fourth week in May 2008, and dummy 2 ranged from the second week in August 2007 to the fourth week in May 2008. These intercept dummies can be assigned to economic events, as discussed in section 3.2. 
Despite the inclusion of these variables, and the fact that all the variables except the longshort spread variable and dummy 1 were statistically significant at the $10 \%$ level of significance, the model still explains only about $12 \%$ of the future premium $\left(s_{t+3}-f_{t}\right)$. In making use of the first difference format (see TABLE 3 ) and the fractionally differenced format (see TABLE 4), the results demonstrate that the composed economic variables proposed by the Chiang and Yang (2007) methodology were unable to estimate the realised future spot exchange rate.

TABLE 3: The multi-variable model (OLS) - first differenced approach

\begin{tabular}{|c|c|c|c|c|c|c|}
\hline \multicolumn{4}{|c|}{ Dependent: Difference of $\left(S_{t+3}-f_{t}\right)$} & Coefficient & $\begin{array}{l}\text { Std. } \\
\text { Error }\end{array}$ & $t$-prob. \\
\hline \multicolumn{4}{|c|}{ Inverse of the real-interest rate differential } & -0.071 & 0.028 & $0.012 \star$ \\
\hline \multicolumn{4}{|c|}{ Difference of the AngloGold Ashanti stock return differential } & 0.008 & 0.002 & $0.000 *$ \\
\hline \multicolumn{4}{|c|}{ Difference of the long-short spread } & -0.041 & 0.055 & 0.450 \\
\hline \multicolumn{4}{|l|}{ Dummy l } & 0.085 & 0.052 & 0.104 \\
\hline \multicolumn{4}{|l|}{ Dummy 2} & -0.072 & 0.040 & $0.073 * \star$ \\
\hline \multicolumn{4}{|l|}{$\operatorname{AR}(1)$} & 0.276 & 0.065 & $0.000 \star$ \\
\hline \multicolumn{4}{|c|}{ Constant parameter $\left(\mathrm{v}_{0}\right)$} & 0.018 & 0.020 & 0.374 \\
\hline R-squared & 0.120 & Prob.(F-statistic) & 0.000 & & & \\
\hline Adjusted R-squared & 0.097 & AIC & -0.640 & \multicolumn{2}{|c|}{ Durbin Watson } & 1.965 \\
\hline
\end{tabular}

\section{Source: Compiled by authors}

* Statistically significant at the $5 \%$ level

** Statistically significant at the $10 \%$ level

TABLE 4: The $\operatorname{ARCH}(1,0)$ multi-variable model - fractionally differenced approach

\begin{tabular}{|c|c|c|c|c|c|c|}
\hline \multicolumn{4}{|c|}{ Dependent: Fractionally differenced $\left(S_{t+3}-f_{t}\right)$} & Coefficient & $\begin{array}{l}\text { Std. } \\
\text { error }\end{array}$ & $t$-prob. \\
\hline \multicolumn{4}{|c|}{ Fractionally differenced real-interest rate differential } & -0.026 & 0.012 & $0.033^{\star}$ \\
\hline \multicolumn{4}{|c|}{ Fractionally differenced Sappi Limited stock return differential } & -0.030 & 0.002 & $0.000 *$ \\
\hline \multicolumn{4}{|c|}{ Fractionally differenced long-short spread } & 0.084 & 0.032 & $0.008 *$ \\
\hline \multicolumn{4}{|c|}{ Intercept $(\alpha)$} & -0.417 & 0.046 & $0.000 *$ \\
\hline \multicolumn{7}{|c|}{ Variance equation } \\
\hline \multicolumn{4}{|l|}{ Intercept } & 0.019 & 0.003 & $0.000 *$ \\
\hline \multicolumn{4}{|l|}{ Residual $(-1)^{\wedge} 2$} & 0.733 & 0.194 & $0.000 *$ \\
\hline R-squared & 0.139 & AIC & -0.126 & \multicolumn{2}{|c|}{ Log likelihood } & 21.303 \\
\hline Adjusted R-squared & 0.128 & SIC & -0.040 & \multicolumn{2}{|c|}{ Sum squared residuals } & 19.650 \\
\hline
\end{tabular}

\section{Source: Compiled by authors}

* Statistically significant at the $5 \%$ level. The $A R(1)$ variable was unable to provide a statistically significant contribution in eliminating serial correlation which led to the use of an ARCH model to eliminate the presence of serial correlation and heteroskedasticity.

In order to improve on the results reported in TABLES $\mathbf{3}$ and $\mathbf{4}$, the use of alternative economic variables was investigated. The future premium $\left(s_{t+3}-f_{t}\right)$ was also substituted with the realised future spot exchange rate as the dependent variable, in order to compensate for the mechanical 
approach followed in determining the forward exchange rate. Evidence indicates that the inverse of the real interest rate differential and AngloGold Ashanti proxies provided the most significant results. These proxies include the AngloGold Ashanti expected stock return differential, the AngloGold Ashanti ICAPM variable, and the AngloGold Ashanti speed of adjustment series. However, none of the Sappi Limited proxies or the long-run interest rate differential provided any significant contribution to the model. A low Durbin Watson statistic indicated the need for an $A R(1)$ variable to eliminate the presence of serial correlation. Furthermore, the Chow breakpoint test and the Cusum test indicated that there may be structural breaks, which required intercept dummies. These dummies were subsequently included. Dummy 1 span from the first week in July 2006 to the fourth week in May 2008, Dummy 2 span from the second week in July 2006 to the fourth week in May 2008, and Dummy 3 span from the first week in February 2006 to the third week in April 2006. The current spot exchange rate was also included as an explanatory variable, because all the previous evidence implied that the flawed manner of calculating the forward exchange rate considered only the present spot exchange rate and a small carry cost. The current spot exchange rate also had a significant impact on the improved multi-variable model. Furthermore, the Nominal Effective Exchange rate (NEER) was examined and included as an additional possible explanatory variable, but failed to provide a statistically significant contribution and was, therefore, removed from the improved multi-variable model. The improved results for the first difference data format are reported in TABLE 5. Since the fractionally differenced data format did not render major improvements on the first difference data format results reported in TABLES $\mathbf{5}$ and $\mathbf{6}$, only the results of the first difference approach are reported here.

TABLE 5: Improved multi-variable model - first differenced approach

\begin{tabular}{|c|c|c|c|c|c|c|}
\hline \multicolumn{4}{|c|}{ Dependent: Difference of $S_{t+3}$} & Coefficient & $\begin{array}{l}\text { Std. } \\
\text { error }\end{array}$ & $t$-prob. \\
\hline \multicolumn{4}{|l|}{ Difference of $S_{t}$} & 0.228 & 0.093 & $0.015^{\star}$ \\
\hline \multicolumn{4}{|c|}{ Difference of the actual inflation rate differential $(-1)$} & -0.035 & 0.022 & 0.115 \\
\hline \multicolumn{4}{|c|}{ Inverse of the real interest rate differential $(-1)$} & 0.052 & 0.021 & $0.014 *$ \\
\hline \multicolumn{4}{|c|}{ stock return differential $(-1)$} & -0.005 & 0.002 & $0.036 *$ \\
\hline \multicolumn{4}{|l|}{ Dummy 1} & 0.363 & 0.130 & $0.006^{*}$ \\
\hline \multicolumn{4}{|l|}{ Dummy 2} & -0.351 & 0.133 & $0.009 *$ \\
\hline \multicolumn{4}{|l|}{ Dummy 3} & 0.096 & 0.044 & $0.032 \star$ \\
\hline \multicolumn{4}{|c|}{ AngloGold Ashanti ICAPM (-2) } & -0.054 & 0.035 & 0.126 \\
\hline \multicolumn{4}{|c|}{ AngloGold Ashanti speed of adjustment series $(-6)$} & 0.044 & 0.019 & $0.025 *$ \\
\hline \multicolumn{4}{|l|}{$\operatorname{AR}(1)$} & 0.154 & 0.072 & $0.034^{\star}$ \\
\hline \multicolumn{4}{|c|}{ Constant parameter $\left(\mathrm{v}_{0}\right)$} & -0.085 & 0.050 & $0.087 \star \star$ \\
\hline R-squared & 0.194 & Prob.(F-statistic) & 0.000 & & & \\
\hline Adjusted R-squared & 0.153 & AIC & -1.370 & \multicolumn{2}{|c|}{ Durbin Watson } & 1.984 \\
\hline
\end{tabular}

Source: Compiled by authors

* Statistically significant at the $5 \%$ level

$\star \star$ Statistically significant at the $10 \%$ level 
The results reported in TABLE $\mathbf{5}$ demonstrate that all of the variables were significant, except for the actual inflation rate differential and the AngloGold Ashanti ICAPM variable. This model was able to explain $19 \%$ of the realised spot exchange rate. The actual inflation rate differential, the inverse of the real interest rate differential, and the AngloGold Ashanti stock return differential were lagged with one period. The AngloGold Ashanti ICAPM was also lagged with 2 periods, while the AngloGold Ashanti speed of adjustment variable was lagged with 6 periods. All the variables had a positive relationship with the realised spot exchange rate, except the actual inflation rate differential, Dummy 2, the AngloGold Ashanti ICAPM variable, and the AngloGold Ashanti stock return differential variable. However, including the entire AngloGold Ashanti proxy variables in the model may have led to a decrease in degrees of freedom. Thus, an alternative was to generate an AngloGold Ashanti principal component, consisting of the AngloGold Ashanti stock return differential, the AngloGold Ashanti speed of adjustment proxy, and the AngloGold Ashanti ICAPM proxy. This AngloGold Ashanti principal component was lagged with five periods, while both the actual inflation rate differential and the inverse of the real interest rate differential were lagged with one period. The results demonstrate (see TABLE 6) that the AngloGold Ashanti principal component had a negative effect on the improved multi-variable model, as it caused the current spot exchange rate to become statistically insignificant. This model's ability to explain the realised spot exchange rate also decreased to $16 \%$.

TABLE 6: Improved multi-variable model with AngloGold Ashanti principal component - first differenced approach

\begin{tabular}{|c|c|c|c|c|c|c|}
\hline \multicolumn{4}{|c|}{ Dependent: Difference of $S_{t+3}$} & Coefficient & $\begin{array}{l}\text { Std. } \\
\text { error }\end{array}$ & $t$-prob. \\
\hline \multicolumn{4}{|c|}{ Difference of $S_{t}$} & 0.103 & 0.071 & 0.145 \\
\hline \multicolumn{4}{|c|}{ Difference of the actual inflation rate differential $(-1)$} & -0.041 & 0.022 & $0.062 * *$ \\
\hline \multicolumn{4}{|c|}{ Inverse of the real interest rate differential $(-1)$} & 0.057 & 0.021 & $0.007^{\star}$ \\
\hline \multicolumn{4}{|c|}{ AngloGold Ashanti principal component $(-5)$} & 0.008 & 0.007 & 0.220 \\
\hline \multicolumn{4}{|l|}{ Dummy l } & 0.313 & 0.127 & $0.015 *$ \\
\hline \multicolumn{4}{|l|}{ Dummy 2} & -0.294 & 0.130 & $0.025^{\star}$ \\
\hline \multicolumn{4}{|l|}{ Dummy 3} & 0.087 & 0.045 & $0.055 * \star$ \\
\hline \multicolumn{4}{|c|}{$\operatorname{AR}(1)$} & 0.162 & 0.070 & $0.021^{*}$ \\
\hline \multicolumn{4}{|c|}{ Constant parameter $\left(\mathrm{v}_{0}\right)$} & -0.013 & 0.014 & 0.362 \\
\hline R-squared & 0.163 & Prob.(F-statistic) & 0.000 & & & \\
\hline Adjusted R-squared & 0.129 & AIC & -1.356 & \multicolumn{2}{|c|}{ Durbin Watson } & 1.991 \\
\hline
\end{tabular}

\section{Source: Compiled by authors}

* Statistically significant at the $5 \%$ level

** Statistically significant at the $10 \%$ level

These results, therefore, confirm that using first differenced stationary data means that one is unable to explain the realised future spot exchange rate effectively. This may be due to the first differencing format approach, which can strip the economic variables of their full explanatory capabilities. In order to justify this statement the following section will report on the investigation of the use of non-stationary, level time series data to estimate the realised future spot exchange rate. 


\subsection{The second approach (non-stationary data format)}

The main objection to working with non-stationary, level data is the possibility of ending up with spurious results. In order to prevent spurious results, the non-stationary, level data was incorporated into a standard OLS model to acquire preliminary results. Thereafter, a BreuschGodfrey serial correlation LM test was run to determine whether serial correlation was still present among the explanatory variables, after which the presence of heteroskedasticity was tested by means of White's test for heteroskedasticity. Based on the results of White's test, the appropriate ARCH model was applied and checks done to ensure that there are no remaining ARCH effects. Finally, the ARCH model's residuals were tested for the presence of a unit root, and this was followed by testing whether the residuals are normally distributed to ensure that the variance of the residual is identical and uncorrelated (white noise). Besides the above precautions, individual economic variables instead of composed variables were used. After effecting the above changes, the results indicated that the current spot exchange rate no longer provided a statistically significant contribution to explaining the realised future spot exchange rate. The U.S.A. expected inflation rate, the South African actual inflation rate, the South African and the U.S.A. 91-day T-Bill rates, and the U.S.A. 10-year government bond yield rates provided the best statistically significant results of all the individual variables. The financial proxies for market behaviour included the Sappi ICAPM variable and the difference between the weekly closing prices of the AngloGold Ashanti dual-listed stock of the JSE and the NySE, expressed in USD terms.

In addition to the above variables, some cross-exchange rates were also included: these include the Euro/USD, the Pound/USD, the ZAR/Euro, and the ZAR/Pound exchange rates. Crossexchange rates are useful in modelling exchange rates for two reasons: firstly, both the Euro and the Pound have a significant spill-over influence on the ZAR; and secondly, exchange rates among different currencies can be inconsistent, which may lead to arbitrage and thus an additional supply/demand force that can influence the current position of the ZAR.

Since the inclusion of these variables led to the presence of serial correlation and heteroskedasticity, an ARCH model was fitted. The results reported in TABLE 7 demonstrate that all the variables, including the variance residual, were statistically significant at the $5 \%$ level and explain $66 \%$ of the realised future spot exchange rate. The AIC and SIC were relatively low, while the log likelihood statistic was relatively high, implying a good fit. The presence of a unit root among the residuals was also rejected, as reported by the Augmented Dickey-Fuller (ADF) test and Dickey-Fuller Generalised Least Squares (DF-GLS) test, thus indicating that this is not a spurious model. This was also verified by testing for stationarity as the null hypothesis with the KPSS test (after Kwaitkowski, Pillips, Schimdt \& Shin, 1992). Furthermore, there were no remaining $A R C H$ effects in the model and the Jarque-Bera probability statistic indicated that the hypothesis of normally distributed residuals could not be rejected.

Although the variance residuals in the ARCH models are just over 1 , indicating the possibility of instability, it is still more significant to 1 , thus the model is still providing statistically significant results.

However, the Chow breakpoint test and the Cusum test indicated that this model exhibited structural breaks, which implied that the following three dummies had to be incorporated in the model. Dummy 1 was included for the effects of the preliminary shocks of the financial crisis, which extended from the third week in July 2007 to the fourth week in May 2008. Dummies 2 and 3 were included for the Russian gas crisis that occurred from the first week in February 2006 to the 
fourth week in May 2008 and the first week in February 2006 to the third week in April 2006, respectively. Dummy 4 span from the first week in March 2005 to the fourth week in May 2008 and covers the announcement of the U.S.A. president's second term (January 2005), the announcement of North Korea's nuclear intentions (October 2006) and the commodity crisis from 2007 to 2008.

TABLE 7: $\quad \operatorname{ARCH}(1,0)$ estimation in level format

\begin{tabular}{|c|c|c|c|c|c|c|}
\hline \multicolumn{4}{|l|}{ Dependent: $S_{t+3}$} & Coefficient & $\begin{array}{l}\text { Std. } \\
\text { error }\end{array}$ & $t$-prob. \\
\hline \multicolumn{4}{|c|}{ U.S.A. expected inflation rate } & -0.031 & 0.006 & $0.000 *$ \\
\hline \multicolumn{4}{|c|}{ U.S.A. 91-day T-Bill rate } & 0.241 & 0.017 & $0.000 \star$ \\
\hline \multicolumn{4}{|c|}{ U.S.A. 10-year government bond yield rate } & 0.137 & 0.041 & $0.008 *$ \\
\hline \multicolumn{4}{|c|}{ South African 91-day T-Bill rate } & 0.148 & 0.012 & $0.000 *$ \\
\hline \multicolumn{4}{|c|}{ South African actual inflation rate } & -0.061 & 0.008 & $0.000 *$ \\
\hline \multicolumn{4}{|c|}{ AngloGold Ashanti price difference in USD terms } & -0.072 & 0.023 & $0.002 \star$ \\
\hline \multicolumn{4}{|c|}{ Sappi Limited ICAPM } & -0.122 & 0.025 & $0.000 *$ \\
\hline \multicolumn{4}{|c|}{ Euro/USD exchange rate in ZAR terms } & 0.944 & 0.048 & $0.000 *$ \\
\hline \multicolumn{4}{|c|}{ Pound/USD exchange rate in ZAR terms } & -0.532 & 0.037 & $0.000 *$ \\
\hline \multicolumn{4}{|c|}{ Constant parameter $\left(\mathrm{v}_{0}\right)$} & 3.207 & 0.398 & $0.000 *$ \\
\hline \multicolumn{7}{|c|}{ Variance equation } \\
\hline \multicolumn{4}{|l|}{ Intercept } & 0.007 & 0.002 & $0.003 *$ \\
\hline \multicolumn{4}{|l|}{ Residual(-1)^2 } & 1.132 & 0.234 & $0.000 *$ \\
\hline R-squared & 0.657 & AIC & -0.014 & \multicolumn{2}{|l|}{ Log likelihood } & 13.651 \\
\hline Adjusted R-squared & 0.644 & SIC & 0.158 & \multicolumn{2}{|c|}{ Sum squared residuals } & 26.195 \\
\hline
\end{tabular}

\section{Source: Compiled by authors}

* Statistically significant at the $5 \%$ level

Although these dummies were required to compensate for the abovementioned structural breaks, an alternative approach was followed. As most of these events causing the structural breaks had an influence on the world's gold price and Brent oil price, an attempt was made to improve the accuracy of the explanation of the realised spot exchange rate by including the gold price and Brent oil price as additional explanatory variables. These variables can also decrease the number of intercept dummies required in the exchange rate model. The results reported in TABL 8 demonstrate that including the gold and Brent oil price increased the explanatory power of the realised spot exchange rate from $66 \%$ to $71 \%$. The results reported in TABLE 8 illustrate that all the variables were statistically significant at the $5 \%$ level, with a relatively low AIC statistic and SIC statistic. Also, a relatively high log likelihood estimate emphasised the goodness-of-fit of the model. No unit root was found among the residuals, which implied that this was not a spurious model.

All the variables in the ARCH $(1,0)$ model (see TABLE 8) were statistically significant at the $5 \%$ level, including the residual variance coefficient. Negative coefficients were reported for both the South African actual inflation rate and the U.S.A. expected inflation rate. This is an indication of the price competiveness of these countries, where higher product prices may lead to a decrease in the demand for South African goods, thus leading to a decrease in the demand 
for ZAR. The AngloGold Ashanti price difference, in USD terms, and the Sappi ICAPM were also negatively related to the ZAR/USD realised spot exchange rate. This may be due to the negative relationship between stock prices and returns, where a depreciation of the ZAR may lead to an increase in the prices of U.S.A. stocks for South African investors, thus causing the relative return on the U.S.A. stock to decrease.

Furthermore, the Euro/USD exchange rate expressed in ZAR has a positive relationship with the ZAR/USD realised spot exchange rate, the gold price and the Brent oil price (see TABLE 8). However, it was found that the ZAR/USD realised spot exchange rate was negatively related to the Pound/USD exchange rate expressed in ZAR. TABLE 8 also reports a relatively low AIC and SIC statistic and a relatively high log likelihood estimate, implying a good fit. There was no unit root found among the residuals, which implies that this is not a spurious model. Further evidence also indicates that there were no remaining ARCH effects in the model.

\section{TABLE 8: Adjusted ARCH $(1,0)$ estimation in level format}

\begin{tabular}{|c|c|c|c|c|c|c|}
\hline \multicolumn{4}{|c|}{ Dependent: $S_{t+3}$} & Coefficient & $\begin{array}{l}\text { Std. } \\
\text { error }\end{array}$ & $t$-prob. \\
\hline \multicolumn{4}{|c|}{ U.S.A. expected inflation rate } & -0.077 & 0.010 & $0.000^{*}$ \\
\hline \multicolumn{4}{|c|}{ U.S.A. 91-day T-Bill rate } & 0.108 & 0.021 & $0.000 *$ \\
\hline \multicolumn{4}{|c|}{ U.S.A. 10 -year government bond yield rate } & 0.098 & 0.046 & $0.033 *$ \\
\hline \multicolumn{4}{|c|}{ South African 91-day T-Bill rate } & 0.165 & 0.014 & $0.000 *$ \\
\hline \multicolumn{4}{|c|}{ South African actual inflation rate } & -0.066 & 0.010 & $0.000 *$ \\
\hline \multicolumn{4}{|c|}{ AngloGold Ashanti price difference in USD terms } & -0.053 & 0.025 & $0.036 *$ \\
\hline \multicolumn{4}{|l|}{ Sappi Limited ICAPM } & -0.109 & 0.032 & $0.000 *$ \\
\hline \multicolumn{4}{|c|}{ Euro/USD exchange rate in ZAR terms } & 0.534 & 0.079 & $0.000 *$ \\
\hline \multicolumn{4}{|c|}{ Pound/USD exchange rate in ZAR terms } & -0.311 & 0.052 & $0.000 *$ \\
\hline \multicolumn{4}{|l|}{ Brent oil price } & 0.006 & 0.002 & $0.013 *$ \\
\hline \multicolumn{4}{|l|}{ Gold price } & 0.001 & 0.000 & $0.000 *$ \\
\hline \multicolumn{4}{|c|}{ Constant parameter $\left(\mathrm{v}_{0}\right)$} & 3.532 & 0.449 & $0.000 *$ \\
\hline \multicolumn{7}{|c|}{ Variance equation } \\
\hline \multicolumn{4}{|l|}{ Intercept } & 0.009 & 0.003 & $0.001 *$ \\
\hline \multicolumn{4}{|l|}{ Residual(-1)^2 } & 1.045 & 0.243 & $0.000 *$ \\
\hline R-squared & 0.714 & AIC & -0.028 & \multicolumn{2}{|l|}{ Log likelihood } & 17.416 \\
\hline Adjusted R-squared & 0.701 & SIC & 0.173 & \multicolumn{2}{|c|}{ Sum squared residuals } & 21.823 \\
\hline
\end{tabular}

\section{Source: Compiled by authors}

* Statistically significant at the $5 \%$ level

These results confirm that non-stationary, level time series data provides a better explanation of the realised future spot exchange rate. These results also confirm that if the necessary precautions are in place, analysts should not fear the use of non-stationary data when investigating exchange rate theories. However, in order to confirm that the better result was as a consequence of using non-stationary data, and not as a result of a possible improvement in the model, a fractionally differenced data format was used in the final successful model. The results reported in TABLE 9 illustrate that all the variables in the $\operatorname{ARCH}(1,0)$ model provided a statistically significant contribution to the model, explaining $67 \%$ of the realised future spot 
exchange rate.

The sign of each of the variables' coefficients supports the underlying economic theory. By lagging the South African T-Bill rate variable with four periods and the AngloGold Ashanti price difference variable with one period, the explanation of the realised future spot exchange rate was enhanced. Although TABLE 9 provides a weaker explanation of the realised future spot exchange rate compared to the $71 \%$ found in TABLE 8, the fractionally differenced approach provides superior results in comparison with the first differenced approach.

These results therefore confirm that non-stationary, level time series data provides the best results when exchange rate theories are investigated. These results also confirm that the exchange rate puzzle is a pseudo-problem and that economic fundamentals do have the ability to explain the exchange rate puzzle.

TABLE 9: The $\operatorname{ARCH}(1,0)$ comparison with a dummy - fractionally differenced approach

\begin{tabular}{|c|c|c|c|c|c|c|}
\hline \multicolumn{4}{|c|}{ Dependent: Fractionally differenced $S_{t+3}$} & Coefficient & Std. error & $t$-prob. \\
\hline \multicolumn{4}{|c|}{ U.S.A. 91-day T-Bill rate } & 0.195 & 0.045 & $0.000 *$ \\
\hline \multicolumn{4}{|c|}{ U.S.A. expected inflation rate $(-1)$} & -0.046 & 0.023 & $0.048 *$ \\
\hline \multicolumn{4}{|c|}{ U.S.A. 10 -year government bond yield rate } & 0.135 & 0.065 & $0.038 *$ \\
\hline \multicolumn{4}{|c|}{ South African actual inflation rate } & -0.067 & 0.020 & $0.001^{\star}$ \\
\hline \multicolumn{4}{|c|}{ South African 91-day T-Bill rate $(-4)$} & 0.083 & 0.026 & $0.001^{*}$ \\
\hline \multicolumn{4}{|c|}{ South African 10-year government bond yield rate } & 0.252 & 0.042 & $0.000 *$ \\
\hline \multicolumn{4}{|c|}{ AngloGold Ashanti price difference in USD terms $(-1)$} & 0.034 & 0.014 & $0.014^{*}$ \\
\hline \multicolumn{4}{|c|}{ Sappi Limited ICAPM } & -0.051 & 0.024 & $0.038 *$ \\
\hline \multicolumn{4}{|c|}{ Euro/USD exchange rate in ZAR terms } & 0.784 & 0.083 & $0.000 *$ \\
\hline \multicolumn{4}{|c|}{ Pound/USD exchange rate in ZAR terms } & -0.440 & 0.057 & $0.000 *$ \\
\hline \multicolumn{4}{|l|}{ Brent oil price $(-1)$} & -0.010 & 0.002 & $0.000 *$ \\
\hline \multicolumn{4}{|l|}{ Gold price } & 0.002 & 0.001 & $0.003 *$ \\
\hline \multicolumn{4}{|l|}{ Intercept } & -0.006 & 0.152 & 0.968 \\
\hline \multicolumn{7}{|c|}{ Variance equation } \\
\hline \multicolumn{4}{|l|}{ Intercept } & 0.008 & 0.002 & $0.000 *$ \\
\hline \multicolumn{4}{|l|}{ Residual $(-1)^{\wedge} 2$} & 1.025 & 0.223 & $0.000 *$ \\
\hline R-squared & 0.671 & AIC & -0.562 & \multicolumn{2}{|l|}{ Log likelihood } & 82.181 \\
\hline Adjusted R-squared & 0.654 & SIC & -0.344 & \multicolumn{2}{|c|}{ Sum squared residuals } & 11.473 \\
\hline
\end{tabular}

Source: Compiled by authors

* Statistically significant at the $5 \%$ level

$\star \star \star$ Statistically significant at the $15 \%$ level

\section{CONCLUSION}

This study provides a solution for the exchange rate puzzle through the formulation of a model that has the ability to explain the realised future spot exchange rate better than the current forward rate methodology. Two different approaches were followed in modelling the future spot exchange rate. The first approach, which included the use of the Chiang and Yang (2007) 
methodology, made use of stationary time series data, while the second approach made use of non-stationary, level time series data. A preliminary model was first estimated and made use of economic fundamentals within the Chiang and Yang (2007) methodology context. The results, however, suggested that first difference stationary time series data is not suitable for modelling exchange rate theories. Using fractionally differenced time series data provides an enhanced explanation of the realised future spot exchange rate and emphasises that it is important to consider the most appropriate level of integration. These results were, however, still not satisfactory. In addition, the results also imply that the use of composite variables, as suggested by the Chiang and Yang (2007) methodology, will only lead to statistically insignificant results.

A second approach was followed in an attempt to improve the accuracy of the explanation of the realised future spot exchange rate. The second approach modelled individual economic fundamentals in level format, yielding more statistically significant results. These results prove that using economic fundamentals on the same level as that used by market participants (level format) and incorporating economic fundamentals individually in an exchange rate model will enhance the explanation of the realised future spot exchange rate $(71 \%)$. It is thus clear that using non-stationary, level data provides the best explanation of the realised future spot exchange rate. These findings also emphasise the notion that economic analysts should not fear the use of non-stationary, level time series data if the required precautions are in place. These findings further indicate that economic fundamentals can be used to generate a theoretical forward exchange rate that can substitute the current mechanistic calculated forward exchange rate. Finally, these results suggest that the exchange rate puzzle is not a puzzle due to the weak explanatory power of economic theory, but is rather a pseudo-problem due to the fear of using current non-stationary, level time series data to model exchange rate theories.

\section{Acknowledgement}

A special thanks to Paul Styger for all his help with this paper.

\section{LIST OF REFERENCES}

Albuquerque, R. (2008). The forward premium puzzle in a model of imperfect information. Economics letters, 99(3), pp. 461-464.

Diamandis, P.F., Georgoutsos, D.A. \& Kouretas, G.P. (2008). Testing the forward rate unbiasedness hypothesis during the 1920's. International Financial Markets, Institutions and Money, 18(4), pp. $358-373$.

Chiang, T.C. (1991). International asset pricing and equity market risk. Journal of International Money and Finance, 10(3), pp. 349-364.

Chiang, T.C. \& Yang, S.Y. (2007). Foreign exchange rate risk premiums and relative asset return differentials. International Research Journal of Finance and Economics, 8, pp. 181-195.

Citadel. (2010). (Data source, supplied by email).BethC@Citadel.co.za. (Accessed 16 October 2009).

Federal Reserve Board of Governors. (2010). (Data source). [On-line] Available:

http://www.federalreserve.gov'/releases/h15/data.htm. (Accessed 18 March 2010) 
Finance.Yahoo.Com. (2010). (Data source). [On-line] Available: http://finance.yahoo.com/lookup?. (Accessed 18 March 2010)

Granger, C.W.J. \& Newbold, P. (1974). Spurious regressions in econometrics. Journal of Econometrics, 2(2), pp. 111-120.

Gujarati, D.N. (2003). Basic Econometrics, $4^{\text {th }}$ edition. Boston, Mass.: McGraw-Hill.

Huang, R.D. (1990). Risk and parity in purchasing power. Journal of Money, Credit and Banking, 22(3), pp. 338-356.

Ip, Y.K. \& Brooks, L.D. (1996). Capital market information transfer and integration: The case of securities dual traded in the U.S. and Canada. Global Finance Journal, 7(1), pp. 53-65.

Jiang, C. \& Chiang, T. (2000). Do foreign exchange rate risk premiums relate to the volatility in the foreign exchange and equity markets? Applied Financial Economics, 10(1), pp. 95-104.

Korajczyk, R.A. (1985). The pricing of forward contracts for foreign exchange. Journal of Political Economy, 92(2), pp. 346-368.

Kwaitkowski, D., Phillips, P.C.B., Schmidt, P. \& Shin, Y. (1992). Testing the null hypothesis of stationarity against the alternative of a unit root. Journal of Econometrics, 54, pp. 159-178.

Lyons, R.K. (2001). The microstructure approach to exchange rates. Cambridge: MIT press.

Lyons, R.K. (2002). Foreign exchange: Macro puzzles, micro tools. FRBSF Economic Review, (2002), pp. 51-62.

Metastock Database. (Data source, supplied by software).

McGregor BFA Database. (2010). (Data source, supplied by software).

Morley, B. \& Pentecost, દ.J. (1998). Asset pricing and foreign exchange risk: Econometrics evidence for the G7. Journal of International Money and Finance, 17(2), pp. 317-329.

Mussa, M.L. (1990). Exchange rates in theory and in reality. Essays in international finance, no.179 (Des.). [On-line] Available: http://www.princeton.edu/ ies/ies_essays/el79.pdf. (Accessed 3 October 2008)

Obstfeld, M. \& Rogoff, K. (1995). Exchange rate dynamics redux. Journal of Political Economy, 103(3), pp. 624-660.

Obstfeld, M. \& Rogoff, K. (2000). The six major puzzles in international macroeconomics: Is there a common cause? [On-line] Available:

http://repositories.cdlib.org/cgi/viewcotent.cgi?article=1010\&context=iber/cider. . Accessed 10 December 2008)

Ott, M. \& Veugelers, P.T.W.M. (1986). Forward exchange rates in efficiency markets: The effects of news and changes in monetary policy regimes. Federal Reserve Bank of St. Louis Review, 68, pp. 5-15.

Phillips, P.C. (1998). New tools for understanding spurious regressions. Econometrica, 66(6), pp. 1299-1325.

Rand Merchant Bank. (2010). (Data source, supplied by email). sonya.baard@rmb.co.za. (Accessed 16 April 2010)

Sarno, L. \& Taylor, M.P. (2001). The microstructure of the foreign-exchange market: A selective survey of the literature. Princeton Studies in International Economics No. 89. [On-line] Available: http://www.princeton.edu/ ies/ies_studies/s89.pdf. (Accessed 20 February 2010) 
South African Reserve Bank (SARB).( 2010). (Data source). [0n-line] Available:

http://www.resbank.co.za/qbquery/timeseriesquery.aspx. (Accessed 17 April 2010)

U.S.A. Department of Labour: Bureau of Labour Statistics. (2010). (Data source). [0n-line]

Available: http://www.bls.gov/news.release/ppi.toc.htm. (Accessed 17 April 2010)

Van Der Merwe, E.J.( 2003). The exchange rate regime and monetary arrangements in South Africa.

[On-line] Available: http://www.reinventingbrettonwoods.org/2003/madrid/vanderMerwe.doc.

(Accessed 20 ctober 2009)

Van Heerden, P.M.S. (2010). The relationship between the forward-and the realized spot exchange rate in South Africa. Ph.D in Risk Management. Potchefstroom: North West University.

Ventosa-Santaulària, D. (2009). Spurious regression. Journal of Probability and Statistics, pp. 1-27. [On-line] Available: http://downloads.hindawi.com/journals/jps/2009/802975.pdf. (Accessed 16 September 2010). 


\section{APPENDIX}

\section{TABLE A1: The data used and its sources}

\begin{tabular}{|c|c|}
\hline Variables & Sources \\
\hline Daily 3-month forward points & Rand Merchant Bank \\
\hline Weekly S.A. 91-day Treasury Bill rates & South African Reserve Bank's website \\
\hline Weekly U.S.A. 91-day Treasury Bill rates & Federal Reserve Board of Governors' website \\
\hline Daily 10 -year S.A. government bond yields & Citadel \\
\hline Daily 10 -year U.S.A. government bond yields & Citadel \\
\hline Monthly S.A. Producer Price Index (PPI) & South African Reserve Bank's website \\
\hline Monthly U.S.A. Producer Price Index (PPI) & $\begin{array}{l}\text { U.S.A. department of labour: bureau of labour } \\
\text { statistics' website }\end{array}$ \\
\hline $\begin{array}{l}\text { Daily closing prices of S.A. AngloGold Ashanti } \\
\text { Limited, Sappi Limited, Harmony Mining Company } \\
\text { Limited, Sasol Limited, Gold Fields Limited. }\end{array}$ & McGregor BFA database \\
\hline $\begin{array}{l}\text { Daily closing prices of U.S.A. AngloGold Ashanti } \\
\text { Limited, Sappi Limited, Harmony Mining Company } \\
\text { Limited, Sasol Limited, Gold Fields Limited. }\end{array}$ & Finance.yahoo.com \\
\hline Daily Euro/Pond, Pond/ZAR exchange rates & Metastock database \\
\hline Daily Gold, Brent oil prices & Metastock database \\
\hline
\end{tabular}

Source: Compiled by authors 